\title{
sciendo
}

\section{Insulin receptor substrate 1 gene variations and lipid profile characteristics in the type 2 diabetic patients with comorbid obesity and chronic pancreatitis}

\author{
Mariya Marushchak, Uliana Hevko, Inna Krynytska \\ Department of Functional and Laboratory Diagnostics, I. Horbachevsky Ternopil National Medical University, \\ Ternopil, Ukraine \\ E-mail: marushchak@tdmu.edu.ua
}

Objective. Type 2 diabetes mellitus (T2DM) is one of diseases that develops in a setting of polymorbid processes or more often promotes their development, forming in this spectrum the phenomenon of comorbidity. The aim of this study was to evaluate changes in the lipid panel data in T2DM patients with comorbid obesity and chronic pancreatitis (CP) taking into account the C/A polymorphism of the insulin receptor substrate 1 (IRS1) gene (rs2943640).

Methods. The study involved 34 T2DM patients and 10 healthy individuals. The rs 2943640 IRS1 gene polymorphism was genotyped using the TaqMan real-time polymerase chain reaction (PCR) method. Blood serum lipid panel data were determined with commercially available kits on a Cobas 6000 analyzer.

Results. In patients with only T2DM and T2DM + comorbid obesity, an association between IRS1 gene polymorphism (rs2943640) and lipid profile abnormalities with maximum changes of the lipid characteristics recorded in $\mathrm{C} / \mathrm{C}$ genotype carriers was found. Within the $\mathrm{C} / \mathrm{C}$ genotype of the IRS1 gene (rs2943640) in type 2 diabetic patients with comorbid obesity and CP, significantly lower high-density lipoprotein cholesterol (HDL-C) levels and significantly higher levels of triglycerides (TG), non-HDL-C and remnant cholesterol (RC) in relation to type 2 diabetic patients with comorbid obesity were found. At the same time, within the C/A genotype of the IRS1 gene (rs2943640), significant changes of lipid panel data were found in type 2 diabetic patients with comorbid obesity relative to the control group $(\mathrm{p}<0.001)$.

Conclusions. Our data indicate that the presence of the C allele of IRS1 gene (rs2943640) in both homozygous and heterozygous states may indicate increased risk of dyslipidemia in type 2 diabetic patients with comorbidities.

Key words: type 2 diabetes mellitus, comorbidities, IRS1 gene, lipid profile

Diabetes mellitus (DM) is the most common endocrine disease worldwide that threatens the lives of patients if not properly treated (Kaiser et al. 2018; Posokhova et al. 2018; Zheng et al. 2018; Degen et al. 2020; Almulla 2021). The International Diabetes Federation shows that 463 million people worldwide were diagnosed with DM in 2019, and $91 \%$ of them suffered from type 2 diabetes (T2DM) and the cost of DM treatment in the world was more than 727 billion dollars. By 2045, the incidence of DM is projected to rise to 700 million, or more than $10 \%$ of the entire human population (International Diabetes Federation 2019). It should be noted that DM is not only a complex medical but also a social problem, as it

Corresponding author: Mariya Marushchak, MD, PhD, D.Sci, Prof, Department of Functional and Laboratory Diagnostics, 
is characterized by a high risk of developing disabling complications. According to the WHO data, one person dies every six seconds from this disease and its complications on the planet (Voloshin et al. 2019). Thus, every eleventh adult on the planet has DM, most patients have T2DM, and in the coming years the prevalence of T2DM will only increase, especially in low-income countries (Kaiser et al. 2018).

On the other hand, DM is one of those diseases that develops in a setting of polymorbid processes or, more often, promotes their development, forming in this spectrum the phenomenon of pathogenetic interdependence - comorbidity (Melikhova et al. 2018; Marushchak et al. 2019; Voloshin et al. 2019). T2DM is most commonly associated with disorders such as dyslipidemia, obesity and insulin resistance (IR) (Hosseini et al. 2021). In turn, excessive abdominal fat, dysregulation of adipose tissue and inflammation are characterized by increased diabetogenic adipocytokines secretion. This group of cytokines links obesity and dyslipidemia with T2DM as they disrupt insulin action in body organs, including skeletal muscle, brain and liver (Bluher and Stumvoll 2018; Demikhova et al. 2019). Chronic pancreatitis (CP) is also linked to obesity, IR and T2DM (Hevko et al. 2020; Marushchak et al. 2021). For example, in one study $53.3 \%$ of patients with T2DM had exocrine insufficiency of the pancreas, which was determined by the levels of fecal pancreatic elastase-1 (Zhuravleva and Shekhovtsova 2016).

Thus, IR is the most common metabolic disorder associated with only T2DM and T2DM with comorbid obesity or CP. In addition to the important contribution of environmental factors, such as diet and physical activity, genetic variants that affect insulin signaling also play an important role in IR. The insulin receptor substrate 1 (IRS1) gene encodes IRS1 which is a major mediator between the insulin receptor and phosphatidylinositol 3-kinase (PI3K)

Table 1

Characteristics of the study groups $(n=44)$.

\begin{tabular}{llcc}
\hline Group & Patient cohort & $\mathbf{n}$ & $\%$ \\
\hline 1 & $\begin{array}{l}\text { T2DM patients with normal body } \\
\text { weight without CP }\end{array}$ & 10 & 22.7 \\
2 & $\begin{array}{l}\text { T2DM patients with overweight/ } \\
\text { obesity without CP }\end{array}$ & 14 & 31.9 \\
3 & $\begin{array}{l}\text { T2DM patients with overweight/ } \\
\text { obesity with concomitant CP }\end{array}$ & 10 & 22.7 \\
4 & Healthy individuals (control) & 10 & 22.7 \\
\hline
\end{tabular}

Abbreviations: CP - chronic pancreatitis; T2DM - type 2 diabetes mellitus. in the insulin signaling pathway (Qi et al. 2011). The IRS-1 binding and phosphorylation result in the increase of the high-affinity glucose transporter-4 (GLUT4) molecules on the outer membrane of insulin-responsive tissues, including muscle cells and adipose tissue, which leads to increased glucose uptake from the blood into these tissues. Defects in muscle IRS-1 expression and function cause the disruption of the insulin signaling pathway leading to IR and DM (Menting et al. 2013; Bedair et al. 2021).

Polymorphisms in the IRS-1 gene have been associated with IR and T2DM in different populations (So et al. 2000; Yiannakouris et al. 2012; Yousef et al. 2018). However, a study of the effects of IRS-1 gene polymorphisms Gly972Arg and Ala513Pro on IR and T2DM in a non-obese Turkish population didn't reveal a link between these polymorphisms and risk of T2DM developing and its phenotypes (Arikoglua et al. 2014).

Studies of the IRS-1 gene polymorphisms in the Ukrainian population of only T2DM patients or T2DM patients with comorbidities are practically absent. Therefore, the aim of our study was to evaluate changes of the lipid panel data in type 2 diabetic patients with comorbid obesity and chronic pancreatitis taking into account the C/A polymorphism of the IRS1 gene (rs2943640).

\section{Subjects and methods}

Subjects. The study involved 34 type-2 diabetic patients hospitalized to the Endocrinology Department of Ternopil University Hospital (Ternopil, Ukraine) in 2019-2020 and 10 healthy individuals. The distribution of individuals to study groups is presented in Table 1. There were no significant age and sex differences between the groups in this study.

T2DM diagnoses were confirmed according to the 2019 Recommendations of the American Diabetes Association (ADA) (American Diabetes Association 2019). The diagnosis criteria use the level of glycated haemoglobin (HbAlc) $(\geq 6.5 \%)$ and glucose level. CP diagnoses were following the recommendations of the American Pancreatic Association (Conwell et al. 2014).

Body mass index (BMI) was calculated using the formula: body weight $(\mathrm{kg}) /$ height $\left(\mathrm{m}^{2}\right)$. Data were interpreted according to the WHO guidelines: normal weight in the range of $20.0-24.9 \mathrm{~kg} / \mathrm{m}^{2}$; overweight (pre-obesity), $25.0-29.9 \mathrm{~kg} / \mathrm{m}^{2}$; class 1 obesity, $30.0-34.9 \mathrm{~kg} / \mathrm{m}^{2}$; class 2 obesity, $35.0-39.9 \mathrm{~kg} / \mathrm{m}^{2}$ and class 3 obesity, $>40 \mathrm{~kg} / \mathrm{m}^{2}$. 
Inclusion criteria: clinical, laboratory and instrumental signs of T2DM, CP and obesity, no sharp increase (exceeding normal activity not more than 3 times) of blood serum alpha-amylase, lipase, alanine aminotransferase, aspartate aminotransferase, alkaline phosphatase and gamma-glutamyl transferase.

Exclusion criteria from the study: signs of clinically significant neurological, mental, renal, hepatic, immune, gastrointestinal, urogenital disorder; injuries of the musculoskeletal system, skin, sense organs, endocrine system (except T2DM); or uncontrolled hematologic diseases; acute pancreatitis, unstable or life-threatening heart disease; patients with malignant neoplasms who have not been in complete remission for at least 5 years, medication (drug) and alcohol dependence.

The ethical principles included in the Declaration of Human Rights adopted in Helsinki, in 1975, and revised in 2008, were fully respected in our study. The enrolled subjects participated in this study voluntarily, completed and signed a written informed consent. Study protocol was approved by the Ethics Committee of I. Horbachevsky Ternopil National Medical University.

Methods. Level of HbAlc was determined using an automatic biochemical analyzer COBAS 6000 (Roche Hitachi, Germany) and glucose level was determined on an automatic biochemical analyzer BAS INTEGRA 400 (Roche Diagnostics) using a standard set. Blood serum lipid panel data were measured in the Clinical laboratory of Ternopil University Hospital (Ternopil, Ukraine). Total cholesterol (TC), triglycerides (TG) and high-density lipoprotein cholesterol (HDL-C) were determined with commercially available kits on a Cobas 6000 analyzer (Roche Hitachi, Germany).

Friedewald's formula was used to calculate lowdensity lipoprotein cholesterol (LDL-C) levels (if serum TG $<4.5 \mathrm{mmol} / \mathrm{L}$ ) (Piepoli et al. 2016): LDL-C $(\mathrm{mmol} / \mathrm{L})=\mathrm{TC}-\mathrm{HDL}-\mathrm{C}-(0.45 \times \mathrm{TG})$. Non-HDLcholesterol was calculated using the formula (if serum TG $>4.5 \mathrm{mmol} / \mathrm{L}$ ) (Piepoli et al. 2016): non-HDL-C = TC - HDL-C.

Remnant cholesterol (RC) was calculated using the formula (Cosentino et al. 2020): RC $(\mathrm{mmol} / \mathrm{L})=\mathrm{TC}$ - (HDL-C + LDL-C).

Genetic analysis. Genomic DNA was extracted from peripheral blood leukocytes using a commercially available DNA isolation kit (QIAamp Blood DNA Mini Kit, QIAGEN, Germany). The IRS-1 gene rs2943640 C>A polymorphism was genotyped using the TaqMan real-time polymerase chain reaction
(PCR) method (Applied Biosystems, Foster City, CA, USA) (He et al. 2012). Quality control was performed with eight negative control and positive control samples in each 96-well plate. In addition, approximately $10 \%$ of the samples were randomly selected for further quality control, and the concordance rate was $100 \%$. Amplification of the 25-bp IRS-1 sequence including rs2943640 was performed by using PCR with 5'-GAAATGAGAGGAACCCTTCTAACTA-3' as the forward primer and 5'AGGAACTCTTCTAACTATTAGCCC-3' as the reverse primer. Three genotypes of the rs2943640 IRS-1 polymorphism were detected (C/C, C/A and A/A).

Statistical analysis. Study results were analyzed using STATISTICA 7.0 and MedCalc software. The Kolmogorov-Smirnov test was used to compare probability distributions (parametric or non-parametric). Quantitative values, due to their non-parametric distribution, are presented as the median, lower, and upper quartiles-Me (Lq; Uq). Comparative analysis of study groups was performed using the non-parametric Kruskal-Wallis test. Having obtained its probable values $(p<0.05)$, further pairwise comparison of groups was performed using the Mann-Whitney U-test, taking into account Bonferroni correction when assessing statistical significance.

\section{Results}

Table 2 presents the lipid panel data of patients with T2DM regardless of the presence/absence of comorbid obesity or $\mathrm{CP}$, taking into account the genotypes of the IRS1 gene (rs2943640). It was found that lipid panel data in patients with T2DM significantly differed between carriers of genotypes $\mathrm{C} / \mathrm{C}$, $\mathrm{C} / \mathrm{A}$ and $\mathrm{A} / \mathrm{A}$ of the IRS1 gene in the Kruskal-Wallis test by ranks. It should be noted that all studied indices of lipid profile in patients with T2DM also significantly differed from those of the control group. In the control group, $100 \%$ of individuals were carriers of the C/A genotype of the IRS1 gene. Thus, the level of TC was significantly higher in carriers of $\mathrm{C} / \mathrm{C}$ genotype by $69.53 \%$, in carriers of C/A by $21.05 \%$ and in carriers of A/A genotype by $51.25 \%$, respectively; the level of LDL-C by $250.86 \%$, $122.41 \%$ and $198.28 \%$; TG level by $246.75 \%, 24.68 \%$ and $170.13 \%$; the level of non-HDL-C by $253.64 \%$, $94.16 \%$ and $185.71 \%$; RC level by $242.86 \%, 22.86 \%$ and $168.57 \%$ relative to control. Level of HDL-C was significantly lower in $\mathrm{C} / \mathrm{C}$ genotype carriers by $141.86 \%$, in C/A carriers by $50.72 \%$ and in $\mathrm{A} / \mathrm{A}$ genotype carriers by $89.09 \%$ vs control data (Table 2 , Table 3). 
Table 2

Lipid profile characteristics in type 2 diabetic patients taking into account the $\mathrm{C} / \mathrm{A}$ polymorphism of the IRS1 gene (rs2943640).

\begin{tabular}{lcccl}
\hline Index & C/C & C/A & A/A & Kruskal-Wallis criterion \\
\hline TC $(\mathrm{mmol} / \mathrm{L})$ & $6.12(5.88 ; 6.42)$ & $4.37(3.64 ; 5.20)$ & $5.46(4.27 ; 6.58)$ & $\mathrm{H}=23.19 ; \mathrm{p}<0.001^{*}$ \\
HDL-C $(\mathrm{mmol} / \mathrm{L})$ & $0.86(0.78 ; 0.94)$ & $1.38(0.99 ; 2.05)$ & $1.10(0.92 ; 1.27)$ & $\mathrm{H}=16.11 ; \mathrm{p}<0.001^{*}$ \\
LDL-C $(\mathrm{mmol} / \mathrm{L})$ & $4.07(3.89 ; 4.37)$ & $2.58(1.28 ; 3.25)$ & $3.46(2.44 ; 4.51)$ & $\mathrm{H}=22.11 ; \mathrm{p}<0.001^{*}$ \\
TG $(\mathrm{mmol} / \mathrm{L})$ & $2.67(2.26 ; 2.86)$ & $0.96(0.83 ; 2.06)$ & $2.08(1.14 ; 2.35)$ & $\mathrm{H}=18.88 ; \mathrm{p}<0.001^{*}$ \\
non-HDL-C $(\mathrm{mmol} / \mathrm{L})$ & $5.34(5.06 ; 5.56)$ & $2.99(1.59 ; 4.28)$ & $4.40(2.95 ; 5.76)$ & $\mathrm{H}=22.78 ; \mathrm{p}<0.001^{*}$ \\
RC $(\mathrm{mmol} / \mathrm{L})$ & $1.20(1.02 ; 1.30)$ & $0.43(0.37 ; 0.93)$ & $0.94(0.51 ; 1.06)$ & $\mathrm{H}=18.88 ; \mathrm{p}<0.001^{*}$ \\
\hline
\end{tabular}

Abbreviations: HDL-C - high-density lipoprotein cholesterol; LDL-C - low-density lipoprotein cholesterol; RC - remnant cholesterol; TC - total cholesterol; TG - triglycerides. ${ }^{\star}$ - statistically significant results.

Table 3

Lipid profile characteristics of the control group taking into account the C/A polymorphism of the IRS1 gene (rs2943640).

\begin{tabular}{lcccccc}
\hline Index/Genotype & $\begin{array}{c}\mathrm{TC} \\
(\mathbf{m m o l} / \mathbf{L})\end{array}$ & $\begin{array}{c}\text { HDL-C } \\
(\mathbf{m m o l} / \mathbf{L})\end{array}$ & $\begin{array}{c}\text { LDL-C } \\
(\mathbf{m m o l} / \mathbf{L})\end{array}$ & $\begin{array}{c}\text { TG } \\
(\mathbf{m m o l} / \mathbf{L})\end{array}$ & $\begin{array}{c}\text { non-HDL-C } \\
(\mathbf{m m o l} / \mathbf{L})\end{array}$ & $\begin{array}{c}\text { RC } \\
(\mathbf{m m o l} / \mathbf{L})\end{array}$ \\
\hline $\mathrm{C} / \mathrm{C}(\mathrm{n}=0)$ & - & - & - & - & - & - \\
$\mathrm{C} / \mathrm{A}(\mathrm{n}=10)$ & $3.61(3.38 ; 3.82)$ & $2.08(1.98 ; 2.14)$ & $1.16(1.00 ; 1.37)$ & $0.77(0.71 ; 0.84)$ & $1.54(1.38 ; 1.72)$ & $0.35(0.32 ; 0.38)$
\end{tabular}

$\mathrm{A} / \mathrm{A}(\mathrm{n}=0)$

Abbreviations: HDL-C - high-density lipoprotein cholesterol; LDL-C - low-density lipoprotein cholesterol; RC - remnant cholesterol; TC - total cholesterol; TG - triglycerides.

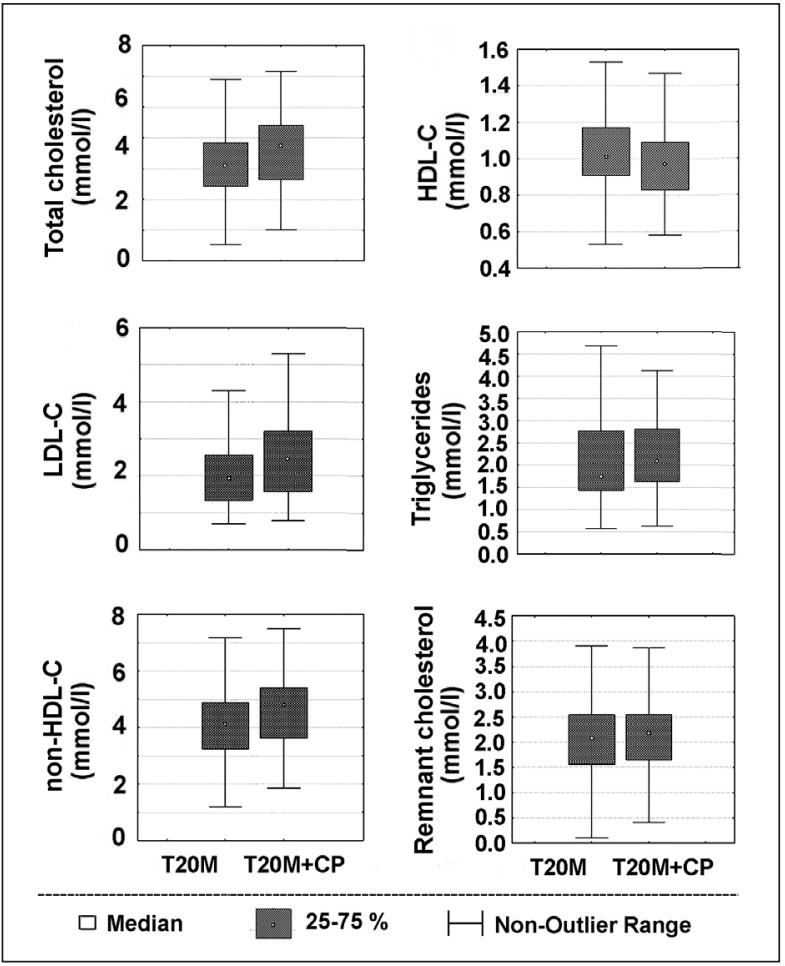

Figure 1. Serum lipid panel data of type 2 diabetic patients with comorbidities, carriers of the C/C genotype of the IRS1 gene (rs2943640). Abbreviations: T2DM - diabetes mellitus type 2; Ob - obesity; $\mathrm{CP}$ - chronic pancreatitis; IRS1 - insulin receptor substrate 1 gene; TG - triglycerides; HDL-C - highdensity lipoprotein cholesterol; LDL-C - low-density lipoprotein cholesterol; RC - remnant cholesterol.
A multiple comparison of the TC level between the studied genotypes of the IRS1 gene revealed a significantly higher concentration in patients with T2DM carriers of the $\mathrm{C} / \mathrm{C}$ genotype (by $40.1 \%$ ) relative to the carriers of the C/A genotype $(\mathrm{p}<0.001)$; the level of HDL-C was significantly higher in carriers of C/A genotype (by $60.5 \%$ ) compared to carriers of $\mathrm{C} / \mathrm{C}$ genotype $(p<0.001)$; the level of LDL-C was significantly higher in carriers of $\mathrm{C} / \mathrm{C}$ genotype (by $57.8 \%$ ) compared to carriers of $\mathrm{C} / \mathrm{A}$ genotype $(\mathrm{p}<0.001)$; the level of TG was significantly higher in carriers of C/C genotype (by 57.8\%) compared to carriers of $\mathrm{C} /$ A genotype $(\mathrm{p}<0.001)$; the level of non-HDL- $\mathrm{C}$ was significantly higher in carriers of the $\mathrm{C} / \mathrm{C}$ genotype (by 78.6\%) compared to carriers of the C/A genotype $(\mathrm{p}<0.001)$ and the level of RC was significantly higher in carriers of the $\mathrm{C} / \mathrm{C}$ genotype (by $79.1 \%$ ) in relation to carriers of C/A genotype of the IRS1 gene $(\mathrm{p}<0.001)$. It should be noted that the maximum changes of lipid profile in patients with T2DM were recorded in carriers of C/C genotype of the IRS1 gene.

Analysis of the effect of IRS1 gene polymorphism (rs2943640) on lipid panel data did not show a clear relationship between changes of the studied lipid profile characteristics taking into account polymorphic variants of the IRS1 gene in patients with only T2DM and T2DM with comorbid obesity and CP. However, in type 2 diabetic patients with comorbid obesity, TC was significantly higher in C/C genotype 
carriers (9.7\%) than in C/A genotype carriers, and non-HDL-C level was significantly higher in carriers of $\mathrm{C} / \mathrm{C}$ genotype (by $11.5 \%$ ) relative to carriers of the C/A genotype of the IRS1 gene. It should be noted that in patients with T2DM+obesity, carriers of the A/A genotype, relative to other polymorphic variants of the IRS1 gene, no significant changes of lipid profile were recorded.

Analyzing the lipid panel data within the C/C genotype of the IRS1 gene (rs2943640) in type 2 diabetic patients with comorbid obesity and CP found significantly lower HDL-C concentration (by $17.3 \%, p=0.02$ ) and significantly higher levels of TG (by $24.8 \%, \mathrm{p}=0.04$ ), non-HDL-C (by $12.3 \%$, $\mathrm{p}=0.03$ ) and RC (by 24.5\%, $\mathrm{p}=0.04$ ), regarding type 2 diabetic patients with comorbid obesity (Figure 1).

Analyzing the lipid panel data within the C/A genotype of the IRS1 gene (rs2943640) in type 2 diabetic patients with comorbid obesity found significantly lower HDL-C concentration (by 2.19 times) and significantly higher levels of TC (by 1.48 times), LDL-C (by 2.98 times), TG (by 2.84 times), non-HDL-C (by 2.83 times) and RC (by 2.83 times) vs control group $(\mathrm{p}<0.001)$ (Figure 2$)$. Within the A/A genotype of the IRS1 gene (rs2943640) no significant changes of the studied indices of the lipid panel data in type 2 diabetic patients depending on comorbid obesity or $\mathrm{CP}$ were found.

Comparison of the obtained lipid profile characteristics taking into account the allele status of the IRS1 gene (rs2943640) in type 2 diabetic patients, regardless of the presence/absence of comorbidity, indicates that carriers of the C-allele of the IRS1 gene have significantly higher TC levels (by $25.28 \%$ ), LDL-C (by $41.92 \%$ ), TG (by 71.09\%), non-HDL-C (by 47.17\%) and RC (by 70.69\%), as well as lower level of HDL-C (by $32.63 \%$ ) compared to carriers of A-allele of the studied gene (Table 4).

\section{Discussion}

Insulin resistance, a keystone of both obesity and T2DM, is a condition in which cells respond to insulin in an impaired way with respect to carbohydrate, lipid,

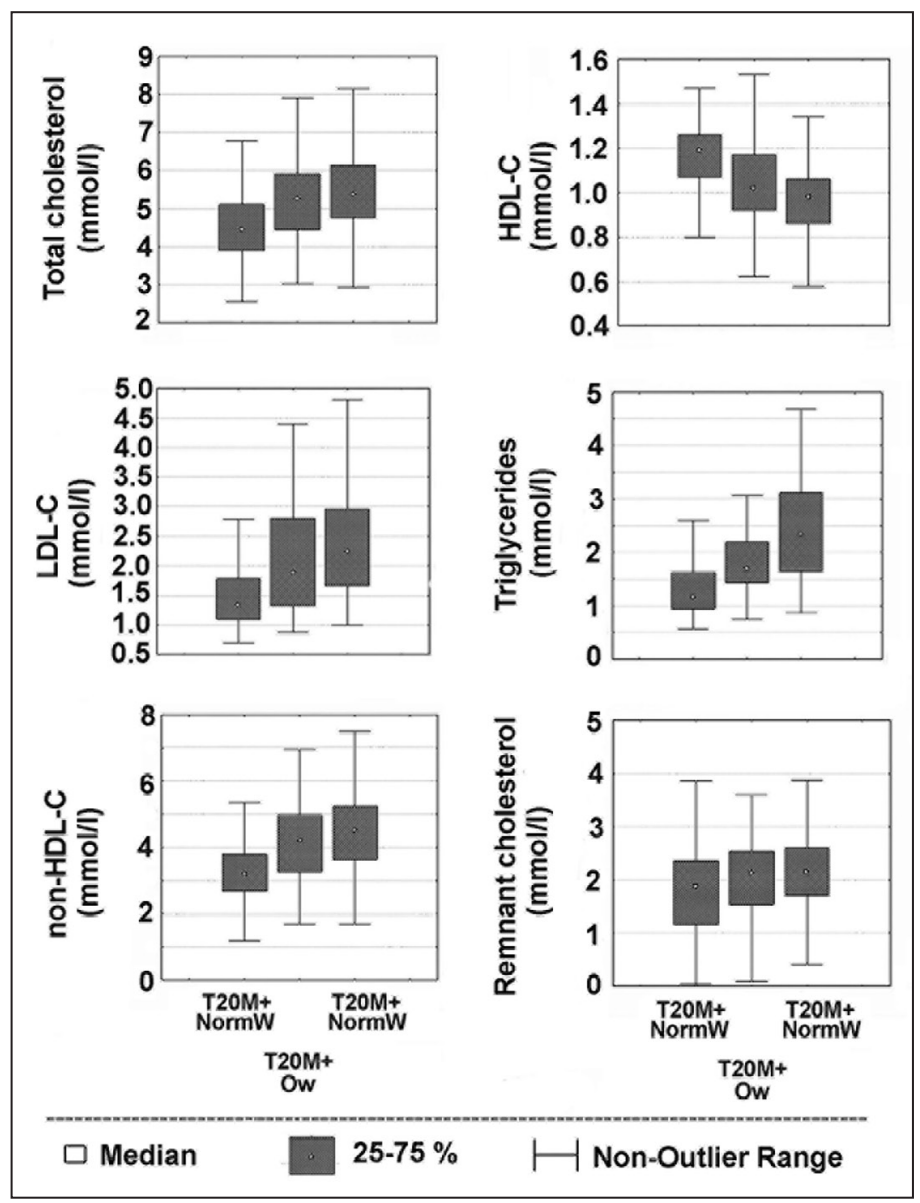

Figure 2. Serum lipid panel data of type 2 diabetic patients with comorbidities, carriers of the C/A genotype of the IRS1 gene (rs2943640). Abbreviations: T2DM - diabetes mellitus type 2; Ob - obesity; IRS1 - insulin receptor substrate 1 gene; TG - triglycerides; HDL-C - high-density lipoprotein cholesterol; LDL-C - low-density lipoprotein cholesterol; RC - remnant cholesterol.

Table 4

Lipid profile characteristics of the type 2 diabetic patients taking into account the allele status of the IRS1 gene (rs2943640).

\begin{tabular}{lccc}
\hline Index & Allele C $(\mathbf{n}=29)$ & Allele A $(\mathbf{n}=37)$ & p-value \\
\hline $\begin{array}{l}\text { TC } \\
(\mathrm{mmol} / \mathrm{L})\end{array}$ & $5.65(3.96 ; 6.12)$ & $4.51(3.87 ; 5.46)$ & $0.025^{\star}$ \\
$\begin{array}{l}\mathrm{HDL}-\mathrm{C} \\
(\mathrm{mmol} / \mathrm{L})\end{array}$ & $0.95(0.85 ; 1.38)$ & $1.26(0.97 ; 1.87)$ & $0.026^{*}$ \\
$\begin{array}{l}\mathrm{LDL}-\mathrm{C} \\
(\mathrm{mmol} / \mathrm{L})\end{array}$ & $3.69(2.34 ; 4.07)$ & $2.60(1.64 ; 3.47)$ & $0.030^{*}$ \\
$\begin{array}{l}\mathrm{TG} \\
(\mathrm{mmol} / \mathrm{L})\end{array}$ & $2.19(0.86 ; 2.67)$ & $1.28(0.85 ; 2.16)$ & $0.025^{*}$ \\
$\begin{array}{l}\text { non-HDL-C } \\
(\mathrm{mmol} / \mathrm{L})\end{array}$ & $4.68(2.72 ; 5.34)$ & $3.18(1.96 ; 4.53)$ & $0.025^{*}$ \\
$\begin{array}{l}\mathrm{RC} \\
(\mathrm{mmol} / \mathrm{L})\end{array}$ & $0.99(0.39 ; 1.20)$ & $0.58(0.38 ; 0.97)$ & $0.025^{*}$ \\
\hline
\end{tabular}

Abbreviations: HDL-C - high-density lipoprotein cholesterol; LDL-C low-density lipoprotein cholesterol; RC - remnant cholesterol; TC - total cholesterol; TG - triglycerides. ${ }^{*}$ - statistically significant results. 
and protein metabolism, resulting in high blood glucose levels. Insulin has many effects on metabolic processes in adipose tissue; therefore, it is one of the most important hormones regulating anti-lipolytic processes, and decrease of the cell sensitivity to its action or impairment of the insulin pathway will affect the metabolism of the adipose tissue (Yang et al. 2018; Al-Sulaiti et al. 2019; Kojta et al. 2020).

The insulin receptor substrate (IRS) proteins are adaptor proteins which play a major role in transmission of insulin-mediated signals from both the insulin and IGF-1 receptors. IRS protein family includes four proteins, namely IRS1, IRS2, IRS3, and IRS4. IRS1, the first identified among others, is encoded by a gene located on the 2q34-37 chromosome. Worth-noting that it is also transcribed as a single exon (Gorgisen et al. 2017). It had been previously shown that IRS1 was a physiological substrate of the insulin receptor and played significant role in insulin signal transmission. The phosphorylation of IRS1, specifically, its tyrosine residues, could interplay with phosphatidylinositol-3 kinase (PI3K), which phosphorylates phosphatidylinositol 2 phosphates (PIP2) into phosphatidyl-inositol 3 phosphates (PIP3), and recruits serine/threonine protein kinase $\mathrm{B}(\mathrm{AKT})$ to the plasma membrane through the plextrin homology domain. Following this, AKT could phosphorylate adenosine monophosphate-activated protein kinase (AMPK), which is an energy sensor in eukaryotic cells and affects GLUT4 translocation to the plasma membrane. Conversely, the dephosphorylation of IRS1 tyrosine residues can potentially inactivate the whole process of insulin signal transduction, causing IR (Copps and White 2012; Liu et al. 2020).

Moreover, mutations in the IRS1 and IRS2 genes are associated with T2DM and susceptibility to IR, as these factors mediate the control of various cellular processes by insulin, and dysregulation of these insulin receptor substrates is associated with PDGF-induced platelet-derived growth factor cells (Zhao et al. 2011; Copps and White 2012). In addition, the IRS1 and IRS2 genes have both common and different regulatory mechanisms, as double-stranded RNA-dependent protein kinase differently regulates IRS1 and IRS2 in HepG2 cells (Yang et al. 2010).

Our results indicate an association between IRS1 gene polymorphism (rs2943640) and lipid profile abnormalities in patients with only T2DM and T2DM+obesity. Research data suggests that genetic variations near the IRS1 gene are associated with decreased obesity, decreased IRS1 expression, and metabolic abnormalities, including IR, dyslipidemia, risk of diabetes development, and decreased adiponectin levels (Kilpelainen et al. 2011). Shu et al. (2010) showed the association of IRS1 (rs2943641) with T2DM, IR and hyperinsulinemia in three European populations. A study by Shalimova (2015) in the Ukrainian population of patients with comorbid pathologies (arterial hypertension and T2DM) found that the polymorphic marker rs1801278 of the IRS1 gene is associated with the development of T2DM, with polymorphism most influencing the violation of lipid and carbohydrate metabolism. The study by Minchenko et al. (2015) has shown that obesity affects the expression of a number of genes associated with the control of glucose metabolism and cell growth, and that IR in obesity is associated with changes in expression levels of many genes, including the IRS1 gene, which contributes to obesity and its complications.

On the other hand, Vassy et al. (2014) did not find any influence of a common genotype, which included 65 gene loci, including the IRS1 gene (rs2943640), on the occurrence of T2DM among individuals with a BMI greater than $30 \mathrm{~kg} / \mathrm{m}^{2}$ compared to those with a BMI below $30 \mathrm{~kg} / \mathrm{m}$.

We found a link between the $\mathrm{C}$ allele of the $\mathrm{C} / \mathrm{C}$ genotype of the IRS1 gene (rs2943640) and the maximum changes in the lipid profile of the type 2 diabetic patients. Rung et al. (2009) also identified a single rs2943641C $>$ T SNP, located ca. $500 \mathrm{~kb}$ downstream from the IRS1 gene, as a T2DM risk factor locus, with the major $\mathrm{C}$-allele being associated with increased risk of T2DM by $19 \%$. Importantly, the rs2943641 C allele was clearly associated with increased fasting- and glucose-stimulated hyperinsulinemia and decreased insulin sensitivity (Rung et al. 2009).

Interestingly, carriers of the $\mathrm{C} / \mathrm{C}$ genotype of the rs2943641 SNP in IRS1 gene, according to Qi et al. (2011), are more successful in weight loss and IR decreasing than individuals without this genotype, while fed high-carbohydrate and low-fat diet. These results indicate a possible long-term effect of the rs2943641 C/C genotype on improving IR under the above mentioned diet.

The potential mechanisms underlying this effect are unknown, but may be associated with lipidinduced IR (Samuel et al. 2010; Chernatska et al.2019). It became increasingly evident that chronic free fatty acids (FFAs) blood plasma elevation played a critical role in the impairment of insulin-associated glucose uptake during obesity, as well as in T2DM (Christiansen et al. 2008; Marushchak et al. 2017). Elevated levels of FFAs impaired glycogen synthesis, transport 
and utilization of glucose in hepatocytes, adipocytes, and skeletal myocytes. Furthermore, lasting exposure of FFAs induced the production of variety of inflammatory factors, as well as activation of c-Jun $\mathrm{N}$-terminal kinase, which accelerated $\beta$-oxidation of FFAs, brought excessive electron flux into the mitochondrial respiratory chain, and subsequently led to the generation of reactive oxygen species (Gao et al. 2010). All mentioned above factors would damage the insulin signaling molecules by lowering the phosphorylation levels of IRS and AKT, and impair the expression and translocation of GLUT4, ultimately resulting in the defective mechanisms of glucose uptake and utilization (Zhang et al. 2019).

Previous studies by a number of research groups have shown that prolonged diets high in fat and elevated levels of FFAs in blood plasma impair insulin signaling by altering IRS1 phosphorylation, leading to decreased activation of IRS1-associated PI3K activity (Yu et al. 2002; Frangioudakis et al. 2005). The results of our study, which indicate an association of rs2943640 polymorphism of the IRS1 gene with lipid profile abnormalities in T2DM patients, may also be associated with IRS1-associated PI3K activity.

This study involved a small sample size; because of it, significant relationships between study factors were difficult to establish. The patients included in T2DM+obesity and T2DM+obesity+ $\mathrm{P}$ groups, were not randomly selected, potentially resulting in selection bias. While we cannot support the assumption that study participants represent the population of type 2 diabetic patients with comorbid obesity and CP in Ternopil region, but obtained results give grounds for further studies with larger sample sizes reflecting a more inclusive population.

In conclusion, in patients with only T2DM and T2DM+comorbid obesity, an association was found between IRS1 gene polymorphism (rs2943640) and lipid profile abnormalities, with maximum changes of the lipid panel data recorded in $\mathrm{C} / \mathrm{C}$ genotype carriers. Within the $\mathrm{C} / \mathrm{C}$ genotype of the IRS1 gene (rs2943640) in type 2 diabetic patients with comorbid obesity and chronic pancreatitis, significantly lower HDL-C levels and significantly higher levels of TG, non-HDL-C and $\mathrm{RC}$ in relation to type 2 diabetic patients with comorbid obesity were found. At the same time, within the C/A genotype of the IRS1 gene (rs2943640), significant changes of lipid panel data were found in type 2 diabetic patients with comorbid obesity relative to the control group $(\mathrm{p}<0.001)$. Thus, the presence of the C allele of IRS1 gene (rs2943640) in both homozygous and heterozygous states may indicate increased risk of dyslipidemia in type 2 diabetic patients with comorbidities.

\section{References}

Almulla M. Location-based expert system for diabetes diagnosis and medication recommendation. Kuwait J Sci 48, 67-77, 2021

Al-Sulaiti H, Diboun I, Agha MV, Mohamed FFS, Atkin S, Domling AS. Metabolic signature of obesity-associated insulin resistance and type 2 diabetes. J Transl Med 17, 348, 2019.

American Diabetes Association. Standards of medical care in diabetes-2019 abridged for primary care providers. Clin Diabetes 37, 11-34, 2019.

Arikoglu H, Aksoy HM, Erkoc KD, Asik A, Ipekci SH, Iscioglu F. IRS1 gene polymorphisms Gly972Arg and Ala513Pro are not associated with insulin resistance and type 2 diabetes risk in non-obese Turkish population. Meta Gene 2, 579-585, 2014.

Bedair RN, Magour GM, Ooda SA, Amar EM, Awad AM. Insulin receptor substrate-1 G972R single nucleotide polymorphism in Egyptian patients with chronic hepatitis $C$ virus infection and type 2 diabetes mellitus. Egypt Liver Journal 11, 2, 2021.

Bluher M, Stumvoll M. Diabetes and Obesity. In: Diabetes Complications, Comorbidities and Related Disorders (Bonora E, De Fronzo R. Ed.), Endocrinology, Springer, Cham, 2018.

Chernatska O, Demikhova N, Rudenko T, Demikhov A. Assessment of the lipid profile correction in patients with arterial hypertension and type 2 diabetes mellitus. Azer MJ, 1, 18-22, 2019.

Christiansen E, Urban C, Merten N, Liebscher K, Karlsen KK, Hamacher A. Discovery of potent and selective agonists for the free fatty acid receptor 1 (FFA(1)/GPR40), a potential target for the treatment of type II diabetes. J Med Chem 51, 7061-7064, 2008.

ConwellDL, LeeLS, YadavD, LongneckerDS, MillerFH, MorteleetKJ. American Pancreatic Association PracticeGuidelines in Chronic Pancreatitis: evidence-based report on diagnostic guidelines. Pancreas 43, 1143-1162, 2014.

Copps KD, White MF. Regulation of insulin sensitivity by serine/threonine phosphorylation of insulin receptor substrate proteins IRS1 and IRS2. Diabetologia 55, 2565-2582, 2012. 
Cosentino F, Grant PJ, Aboyans V, et al. 2019 ESC Guidelines on diabetes, pre-diabetes, and cardiovascular diseases developed in collaboration with the EASD. Eur Heart 41, 255-323, 2020.

Degen AS, Krynytska IY, Kamyshnyi AM. Changes in the transcriptional activity of the entero-insular axis genes in streptozotocin-induced diabetes and after the administration of TNF-alpha non-selective blockers. Endocr Regul 54, 160-171, 2020.

Demihova N, Lidiya C, Chernatska O, Mazur T, Aleksakhina T, Demikhov O. The relationship between lipid metabolism and the level of albuminuria with single nucleotide polymorphism -204A>C [rs 3808607] CYP7A1 gene in patients with type 2 diabetes mellitus and diabetic nephropathy. Rom J Diabet Nutr Metab Dis 26, 253-260, 2019.

Frangioudakis G, Ye JM, Cooney GJ. Both saturated and n-6 polyunsaturated fat diets reduce phosphorylation of insulin receptor substrate-1 and protein kinase B in muscle during the initial stages of in vivo insulin stimulation. Endocrinology 146, 5596-5603, 2005.

Gao D, Nong S, Huang X, Lu Y, Zhao H, Lin Y, Man Y, Wang S, Yang J, Li J. The effects of palmitate on hepatic insulin resistance are mediated by NADPH Oxidase 3-derived reactive oxygen species through JNK and p38MAPK pathways. J Biol Chem 285, 29965-29973, 2010.

Gorgisen G, Gulacar IM, Ozes ON. The role of insulin receptor substrate (IRS) proteins in oncogenic transformation. Cell Mol Biol (Noisy-le-grand), 63, 1-5, 2017.

He J, Qiu LX, Wang MY. Polymorphisms in the XPG gene and risk of gastric cancer in Chinese populations. Hum Genet 131, 1235-1244, 2012.

Hevko U, Kozak K, Krynytska I, Marushchak M. Diagnostic value of a complete blood count in type 2 diabetes mellitus and comorbidities. Arch Balk Medical Union 55, 601-607, 2020.

Hosseini S, Alipour M, Zakerkish M, Cheraghian B, Ghandil P. Effects of epigallocatechin gallate on total antioxidant capacity, biomarkers of systemic low-grade inflammation and metabolic risk factors in patients with type 2 diabetes mellitus: the role of FTO-rs9939609 polymorphism. Arch Med Sci 17, 2021.

International Diabetes Federation. Diabetes facts \& figures, 2019. (online) Available at: https://www.idf.org/aboutdiabetes/what-is-diabetes/facts-figures.html. [Accessed 2020 Aug 21].

Kaiser AB, Zhang N, Van Der Pluijm W. Global prevalence of type 2 diabetes over the next ten years (2018-2028). Diabetes 67, 202, 2018.

Kilpelainen TO, Zillikens MC, Stancakova A, et al. Genetic variation near IRS1 associates with reduced adiposity and an impaired metabolic profile. Nat Genet 43, 753-760, 2011.

Kojta I, Chacinska M, Blachnio-Zabielska A. Obesity, Bioactive Lipids, and Adipose Tissue Inflammation in Insulin Resistance. Nutrients 12, 1305, 2020.

Liu M, Wang L, Li X, Wu Y, Yin F, Liu J. Trilobatin ameliorates insulin resistance through IRS-AKT-GLUT4 signaling pathway in C2C12 myotubes and ob/ob mice. Chin Med 15, 110, 2020.

Marushchak M, Krynytska I, Mazur L, Klishch I, Gabor G, Antonyshyn I. The relationship between experimental alimentary obesity and hard tooth tissues mineralization. Jord Med J 51, 25-33, 2017.

Melikhova S, Shevcova V, Zujkova A, Kotova Ju. Studying of comorbid pathology at the 2 type diabetes as the metabolic syndrome. Russ Arch Int Med 8, 366-371, 2018.

Marushchak M, Maksiv K, Krynytska I. ACE gene I/D polymorphism and arterial hypertension in patients with COPD. Pneumologia 68, 114-119, 2019.

Marushchak M, Hevko U, Krynytska I, Danylevych Y, Danchak S, Mazur L. Does comorbid obesity or chronic pancreatitis influence the choice and effectiveness of glucose-lowering therapy in type-2 diabetes patients? Arch Balk Med Union 56, 24-32, 2021.

Menting JG, Whittaker J, Margetts MB, et al. How insulin engages its primary binding site on the insulin receptor. Nature 493, 24-245, 2013.

Minchenko DO, Davydov VV, Budreiko OA, Moliavko OS, Kulieshova DK, Tiazhka OV, Minchenko OH. The expression of CCN2, IQSEC, RSPO1, DNAJC15, RIPK2, IL13RA2, IRS1, and IRS2 genes in blood of obese boys with insulin resistance. Fiziol Zh 61, 10-18, 2015.

Piepoli MF, Hoes AW, Agewall S, et al. European Guidelines on cardiovascular disease prevention in clinical practice. Eur Heart J 37, 2315-2381, 2016.

Posokhova K, Stechyshyn I, Krynytska I, Marushchak M, Birchenko I, Klishch I. Comparative study of the effect of various forms of quercetin on experimental diabetes. Rom J Diabet Nutr Metab Dis 25, 383-388, 2018.

Qi Q, Bray GA, Smith SR, Hu FB, Sacks FM, Qi L. Insulin receptor substrate 1 gene variation modifies insulin resistance response to weight-loss diets in a 2-year randomized trial: the preventing overweight using novel dietary strategies (POUNDS LOST) trial. Circulation 124, 563-571, 2011. 
Rung J, Cauchi S, Albrechtsen A, et al. Genetic variant near IRS1 is associated with type 2 diabetes, insulin resistance and hyperinsulinemia. Nat Genet 41, 1110-1115, 2009.

Samuel VT, Petersen KF, Shulman GI. Lipid-induced insulin resistance: unravelling the mechanism. Lancet 375, 2267-2277, 2010.

Shalimova A. Association of IRS $>1$ gene polymorphism with violations of blood lipid spectrum in patients with essential hypertension and concomitant type 2 diabetes. Family Med 3, 102-104, 2015.

Shu XO, Long J, Cai Q, et al. Identification of new genetic risk variants for type 2 diabetes. PLoS Genet 6, e1001127, 2010.

So WY, Ng MC, Lee SC, Sanke T, Lee HK, Chan JC. Genetics of type 2 diabetes mellitus. Hong Kong Med J 6, 69-76, 2000.

Vassy JL, Hivert MF, Porneala B, Dauriz M, Florez JC, Dupuis J, Siscovick DS, Fornage M, Rasmussen-Torvik LJ, Bouchard C, Meigs JB. Polygenic type 2 diabetes prediction at the limit of common variant detection. Diabetes 63, 2172-2182, 2014.

Voloshin O, Glubochenko O Pankiv I, Glubochenko V, Malkovich N. Peculiarities of phytotherapy of diabetes mellitus through the prism of comorbidity and prevention of complications (review of literature). Int J Endocrinol $15,258-267,2019$.

Yang Q, Vijayakumar A, Kahn BB. Metabolites as regulators of insulin sensitivity and metabolism. Nat Rev Mol Cell Biol 19, 654-672, 2018.

Yang X, Nath A, Opperman MJ, Chan C. The double-stranded RNA-dependent protein kinase differentially regulates insulin receptor substrates 1 and 2 in HepG2 cells. Mol Biol Cell 21, 3449-3458, 2010.

Yiannakouris N, Cooper JA, Shah S, et al. IRS1 gene variants, dysglycaemic metabolic changes and type-2 diabetes risk. Nutr Metab Cardiovas Dis 22, 1024-1030, 2012.

Yousef AA, Behiry EG, Allah WMA, Hussien AM, Abdelmoneam AA, Imam MH, Hikal DM. IRS-1 genetic polymorphism (r.2963G $>$ A) in type 2 diabetes mellitus patients associated with insulin resistance. Appl Clin Genet 11, 99-106, 2018.

Yu C, Chen Y, Cline GW, et al. Mechanism by which fatty acids inhibit insulin activation of insulin receptor substrate-1 (IRS-1)-associated phosphatidylinositol 3-kinase activity in muscle. J Biol Chem 277, 50230-50236, 2002.

Zhang Y, Yang S, Zhang M, Wang Z, He X, Hou Y, Bai G. Glycyrrhetinic acid improves insulin-response pathway by regulating the balance between the Ras/MAPK and PI3K/Akt pathways. Nutrients 11, 604, 2019.

Zhao Y, Biswas SK, Mcnulty PH, Kozak M, Jun JY, Segar L. PDGF-induced vascular smooth muscle cell proliferation is associated with dysregulation of insulin receptor substrates. Am J Physiol Cell Physiol 300, 1375-1385, 2011.

Zheng Y, Ley SH, Hu FB. Global aetiology and epidemiology of type 2 diabetes mellitus and its complications. Nat Rev Endocrinol 14, 88-98, 2018.

Zhuravleva L, Shekhovtsova Yu. Comorbidity of chronic pancreatitis and diabetes type 2: possible options of pharmacoteraphy. Practical Doctor 5, 21-25, 2016. 